\title{
SEMANGAT KERJA SEBAGAI MEDIASI: MOTIVASI KERJA DAN KEPUASAN KERJA KOMITMEN PEGAWAI DINAS PARIWISATA KOTA BATU
}

\author{
Ika Fatma Yulia Winda Jayanti ${ }^{1}$, Rahayu Puji Suci ${ }^{2}$, Arief Purwanto ${ }^{3}$ \\ Pascasarjana Universitas Widyagama Malang \\ Korespondensi: Jl. Taman Borobudur Barat No.35, Mojolangu, Kec. Lowokwaru, Kota Malang, Jawa Timur 65146 \\ e-mail: poppedot87@gmail.com² ; ariefpurwanto@widyagama.ac.id ${ }^{3}$
}

\begin{abstract}
Abstrak: Bukti empiris yang diperoleh dari penelitian ini adalah motivasi kerja yang meningkat mampu meningkatkan komitmen pegawai, begitu juga dengan kepuasan kerja yang semakin baik juga mampu meningkatkan komitmen pegawai, baik secara parsial maupun secara simultan. Semangat kerja mampu memediasi sehingga motivasi kerja dan kepuasan kerja dapat meningkatkan komitmen pegawai Dinas Pariwisata Kota Batu. Hasil ini didukung oleh statistik deskriptif yang rata-rata sedang sampai dengan tinggi.
\end{abstract}

Kata Kunci: motivasi kerja, kepuasan kerja, semangat kerja dan komitmen pegawai

Abstract: Empirical evidence obtained from this study is that increased work motivation can increase employee commitment and better job satisfaction and increase employee commitment, either partially or simultaneously. The wording spirit can mediate so that work motivation and job satisfaction can increase the responsibility of the Batu City Tourism Office employees. This result is supported by descriptive statistics, which mean moderate to high.

Keywords: work motivation, job satisfaction, morale, and employee commitment commitment

\section{PENDAHULUAN}

Pada hakikatnya sebuah organisasi membutuhkan sumberdaya manusia yang berkualitas. Hal ini karena tidak bisa dipungkiri bahwa sumberdaya manusia memegang kendali utama dalam operasional organisasi demi mencapai tujuan yang telah ditetapkan. Sumber daya manusia yang berkualitas sesuai dengan yang tertera pada Undang-Undang Nomor 22 Tahun 1999 tentang Otonomi Daerah yakni hendaknya membawa perubahan strategik pada kualitas SDM yang diperlukan setiap daerah untuk dapat bersaing secara positif dengan daerah lain di Indonesia. Apabila kualitas SDM telah telah terpenuhi maka akan tercipta komitmen pegawai
Secara terminologi, komitmen pegawai merupakan sebuah keadaan dimana seorang pegawai memihak organisasi tertentu serta tujuan-tujuan dan keinginannya untuk mempertahankan keanggotaan dalam organisasi tersebut (Robin dan Judge, 2007). Komitmen pegawai juga dapat diartikan sebagai keinginan yang kuat untuk tetap menjadi anggota dari bagian organisasi, kesediaan untuk mengerahkan tingkat usaha yang tinggi atas nama organisasi, dan keyakinan yang dalam dan penerimaan nilai-nilai serta tujuan organisasi (Luthan, 2008).

Dinas Pariwisata Kota Batu adalah organisasi publik yang salah satu tujuannya adalah meningkatkan pertumbuhan ekonomi dari sektor pariwisata Kota Batu. Dinas Pariwisata Kota Batu dituntut untuk dapat 
memberikan pengaruh positif yang signifikan terhadap berkembangnya kegiatan pariwisata di Kota Batu. Untuk memenuhi tuntutan ini, maka tentunya Dinas Pariwisata harus memiliki sumberdaya manusia (pegawai) yang memiliki komitmen pegawai yang tinggi. Salah satuhal yang berpengaruh terhadap komitmen ini adalah semangat kerja.

Berdasarkan identifikasi masalah yang telah dilakukan, penulis menemukan bahwa pegawai di Dinas Pariwisata Kota Batu memiliki komitmen pegawai yang rendah. Hal iniditunjukkan dengan tidak disiplinnya para pegawai dalam mematuhi jam masuk kantor yang telah ditetapkan yaitu pukul 07.30 WIB.

Terdapat beberapa penelitian empiris yang mendukung motivasi dengan komitmen pegawai yaitu penelitian yang dilakukan oleh Posey (2015) dan Camileri (2007) bahwa motivasi mempunyai pengaruh yang signifikan terhadap komitmen pegawai Penelitian yang mendukung kepuasan kerja dengan komitmen pegawai adalah penelitian yang dilakukan Lambert (2007), Scandurra (1997), dan Peter (1987) bahwa kepuasan kerja mempunyai pengaruh yang signifikan terhadap komitmen pegawai. Adapunpenelitian empiris yang mendukung semangat kerja dengan komitmen pegawai adalah penelitian yang dilakukan oleh Bell Ellis (2013). Oleh karena itu, motivasi dan kepuasan kerja serta semangat kerja memiliki peranan dalam komitmen pegawai

Semangat kerja adalah keinginan dan kesungguhan seseorang mengerjakan pekerjaannya dengan baik serta berdisiplin untuk mencapai produktivitas yang maksimal (Hasibuan, 2004). Dimana semangat kerja dapat diukur melalui presensi pegawai di tempat kerja, disiplin kerja, kerja sama dengan pimpinan atau teman sejawat dalam organisasi, produktivitas kerja, dan tanggungjawabnya terhadap tugaspekerjaan (Dessler, 2001). Tugas adalah hal yang biasa diselesaikan pegawai dalam instansi. Olehkarenaitu, agar dapat menyelesaikan tugas yang diembannya dengan baik maka diperlukan kualitas kehidupan kerja yang mumpuni.

Sulistiyani (2003), motivasi adalah proses pemberian dorongan kepada anak buah agar anak buah dapat bekerja sejalan dengan batasan yang diberikan guna mencapai tujuan organisasi secara optimal. Fenomena yang banyak terjadi adalah banyaknya pegawai yang berkomitmen dengan didasarkan menjadi bagian organisasi, kebanggaan, kesetiaan, dan kontribusinya dalam organisasi tanpa memerhatikan motivasi dan kepuasan kerja yang dapat menumbuhkan komitmen pegawai dalam bekerja.

Ada beberapa faktor yang mempengaruhi komitmen pegawai pada organisasi, yakni ciri pribadi pekerja, termasuk masa jabatannya dalam organisasi, dan variasi kebutuhan dan keinginan yang berbeda dari setiap pegawai. Kemudian, faktor yang mempengaruhi komitmen pegawai ialah ciri pekerjaan, seperti identitas tugas dan kesempatan berinteraksi dengan rekan sekerja. Faktor lain yang mempengaruhi komitmen pegawai juga pengalaman kerja, seperti keterandalan organisasi di masa lampau dan cara pekerjapekerja lain mengutarakan dan membicarakan perasannya mengenai organisasi. Selain hal tersebut di atas, dalam penelitian ini juga melibatkan kepuasan kerja. Sesorang yang memiliki kepuasan tentunya akan memiliki perasaan seperti yang dinyatakan Mangkunegara (2005) bahwa kepuasan kerja adalah perasaan senang atau tidak senang pegawai yang berhubungan dengan pekerjaannya maupun dengan kondisi dirinya.

Robbins (2007) mengatakan bahwa kepuasan kerja merujuk pada sikap umum individu terhadap pekerjaannya. Seseorang dengan kepuasan kerja yang tinggi biasanya memiliki sikap yang positif terhadap pekerjaannya, sementara seseorang yang tidak puas dengan pekerjaannya memiliki sikap negatif terhadap pekerjaannya. Kepuasan kerja menunjukkan adanya kesesuaian antara harapan seseorang yang timbul dengan imbalan yang disediakan oleh pekerjaan.

Menurut Allen dan Meyer (1990) komitmen pegawai memiliki tiga dimensi yakni komitmen afektif yang artinya diakui sebagai ketergantungan afektif individu untuk organisasi dan diidentifikasikan melalui itu. Pegawai akan tetap di organisasi oleh komitmen afektif yang kuat karena mereka ingin tetap dalam organisasi. Kemudian komitmen berkelanjutan yakni teori ini didasarkan pada fakta bahwa agregat individu modal selama waktu sehingga semakin banyak rekaman yang 
dimiliki orang tersebut, maka semakin agregat modal yang dimilikinya. Kemudian yang terakhir ialah komitmen normatif, yakni komitmen yang menunjukkan semacam tugas masuk akal untuk melanjutkan kerja sama dengan organisasi. Orang-orang dengan komitmen normatif yang tinggi merasa bahwa mereka harus tetap berada di dalam organisasi.

Keterbaruan dari penelitian ini adalah dengan mengisi research gap sehingga mampu melengkapi penelitian sebelumnya dengan memasukkan variabel semangat kerja sebagai mediasi yang menghubungkan motivasi terhadap komitmen pegawai serta pengaruh kepuasan kerja terhadap komitmen pegawai.

Menurut Handoko (2000) semangat kerja pegawai akan tercermin dari pegawai yang selalu menunjukkan sikap dan tingkah laku mau bekerja dengan sungguh-sungguh, adanya kesenangan yang mendalam dalam melakukan pekerjaan, adanya kemauan untuk bekerja sama dan merasa puas dalam melaksanakan tugas yang diberikan kepadanya. Semangat kerja pegawai tersebut merupakan suatu sikap mental pegawai untuk bekerja sama dengan lebih giat dan konsekuen, yang harus diwujudkan dalam bentuk disiplin sehingga dapat tercapai hasil kerja yang maksimal.

Tujuan penelitian yang ingin dicapai melalui penelitian ini ialah menjelaskan bukti empiris baik secara lansung maupun tidak langsung dari variabel Motivasi Kerja, Kpuasan Kerja, Semangat Kerja, Komitmen Pegawai

\section{METODE}

Dalam penelitian ini dipilih lokasi Dinas Pariwisata Kota Batu. Peneliti melakukan penelitian pada Dinas Pariwisata dikarenakan ingin mengetahui pengaruh komitmen seluruh pegawai Dinas Pariwisata baik yang memiliki masa kerja lama maupun yang memiliki masa kerja yang masih sebentar. Tentunya dengan dipengaruhi dengan motivasi dan kepuasan kerja serta dengan perantara (mediasi) semangat kerja. Populasi dan sampel dalam penelitian ini adalah seluruh pegawai di Dinas Pariwisata sebanyak 84 orang. PLS merupakan metode analisis yang tidak didasarkan banyak asumsi dan memungkinkan dilakukan analisis dari berbagai indikator variabel laten indikator bersifat refleksif dan formatif. Partial Least Square (PLS) terdapat dua model yaitu inner model dan outer model.

\section{HASIL DAN PEMBAHASAN}

\section{Kepuasan Kerja Berpengaruh Terhadap Komitmen Pegawai}

Dari penggunanan PLS dapat diketahui bahwa t Hitung lebih besar dari t Tabel $(3,960$ $>1,989)$ maka memiliki pengaruh yang signifikan. Kepuasan Kerja pegawai berpengaruh signifikan terhadap komitmen pegawai. Hal ini dikarenakan $\mathrm{p}$-value $<0,05$ maka hipotesis diterima. Adapun indikator dari kepuasan kerja ialah gaji, pekerjaan itu sendiri, rekan kerja dan juga atasan. Hasil ini berarti bahwa kepuasan kerja memiliki pengaruh yang signifikan terhadap komitmen pegawai. Hal ini berarti Hipotesis 1 diterima.

\section{Kepuasan Kerja Terhadap Semangat Kerja}

Dari penggunanan PLS dapat diketahui bahwa t Hitung lebih besar dari t Tabel (4,842 $>1,989)$ maka memiliki pengaruh yang signifikan. Kepuasan Kerja pegawai berpengaruh signifikan terhadap semangat kerja. Hal ini dikarenakan p-value $<0,05$ maka hipotesis diterima. Adapun indikator dari kepuasan kerja ialah gaji, pekerjaan itu sendiri, rekan kerja dan juga atasan. Hasil ini berarti bahwa kepuasan kerja memiliki pengaruh yang signifikan terhadap semangat kerja. Hal ini berarti Hipotesis 2 diterima.

\section{Motivasi Terhadap Komitmen Pegawai}

Dari penggunanan PLS dapat diketahui bahwa t Hitung lebih besar dari t Tabel (3,043 $>1,989)$ maka memiliki pengaruh yang signifikan. Motivasi berpengaruh tidak signifikan terhadap komitmen pegawai. Hal ini dikarenakan $\mathrm{p}$-value $<0,05$ maka hipotesis diterima. Adapun indikator dari motivasi ialah restrukturisasi kerja, sistem imbalan, dan lingkungan kerja. Hasil ini berarti bahwa motivasi memiliki pengaruh yang signifikan terhadap komitmen pegawai. Hal ini berarti Hipotesis 3 diterima. 


\section{Motivasi Terhadap Semangat Kerja}

Dari penggunanan PLS dapat diketahui bahwa t Hitung lebih besar dari t Tabel $(2,456$ $<1,989)$ maka memiliki pengaruh yang signifikan. Hasil ini berarti bahwa motivasi memiliki pengaruh yang signifikan terhadap semangat kerja. Motivasi berpengaruh signifikan terhadap komitmen pegawai. Hal ini dikarenakan $\mathrm{p}$-value $<0,05$ maka hipotesis diterima. Adapun indikator dari kepuasan kerja ialah gaji, pekerjaan itu sendiri, rekan kerja dan juga atasan. Hal ini berarti Hipotesis 4 diterima.

\section{Semangat Kerja Terhadap Komitmen Pegawai}

Dari penggunanan PLS dapat diketahui bahwa t Hitung lebih besar dari t Tabel $(2,814$ $>$ 1,989) maka memiliki pengaruh yang signifkan. Semangat Kerja pegawai berpengaruh signifikan terhadap komitmen pegawai. Hal ini dikarenakan $\mathrm{p}$-value $<0,05$ maka hipotesis diterima. Adapun indikator dari semangat kerja ialah selalu ada di organisasi, kebersamaan, keterlibatan dalam kegiatan transformasi, dan juga sensitivitas kontekstual. Hasil ini berarti bahwa semangat kerja memiliki pengaruh signifikan terhadap komitmen pegawai. Hal ini berarti Hipotesis 5 diterima.

\section{Kepuasan Kerja Melalui Semangat Kerja Terhadap Komitmen Pegawai}

Dari penggunanan PLS dapat diketahui bahwa t Hitung lebih besar dari t Tabel (4,473 $>$ 1,989) maka memiliki pengaruh yang signifikan. Hasil ini berarti bahwa semangat kerja memiliki pengaruh yang signifikan dalam memediasi kepuasan kerja terhadap komitmen pegawai. Hal ini berarti Hipotesis 6 diterima.

Dari uji menggunakan PLS dapat diketahui mengenai semangat kerja sebagai mediasi kepuasan kerja terhadap komitmen pegawai yakni dengan indirect :

$$
\begin{gathered}
\mathrm{X} 2->\mathrm{Z}->\mathrm{Y}=0,027 \times 0,273=0,007 \\
\text { Dan dengan direct }: \\
\mathrm{X} 2->\mathrm{Y}=0,401
\end{gathered}
$$

Perhitungan tesebut menunjukkan bahwa variabel kepuasan kerja secara signifikan berpengaruh terhadap semangat kerja dengan nilai koefisien sebesar 0,027 dan semangat kerja secara signifikan berpengaruh terhadap komitmen pegawai dengan nilai koefisien sebesar 0,273. Sedangkan koefisien jalur dari variabel kepuasan kerja yang dimediasi semangat kerja secara signifikan mampu mempengaruhi komitmen pegawai dengan nilai koefisien sebesar 0,007. Setelah membandingkan nilai antara hubungan langsung dan tidak langsung yang diperoleh dari perhitungan tersebut, maka dapat diambil kesimpulan bahwa nilai koefisien direct lebih besar dari indirect. Dengan demikian dapat dikatakan bahwa kepuasan kerja berperan sebagai mediasi parsial (partial mediation) dari efek tidak langsung. Hal tersebut dapat diartikan ketika kepuasan kerja pada pegawai Dinas Pariwisata meningkat, maka semangat kerja juga akan meningkat yang nantinya juga berimbas pada peningkatan komitmen pegawai pegawai.

\section{Motivasi Melalui Semangat Kerja Terhadap Komitmen Pegawai}

Dari penggunanan PLS dapat diketahui bahwa t Hitung lebih besar dari t Tabel $(2,125$ $>1,989)$ maka memiliki pengaruh yang signifikan. Hasil ini berarti bahwa semangat kerja memiliki pengaruh yang signifikan dalam memediasi motivasi terhadap komitmen pegawai. Hal ini berarti Hipotesis 7 diterima. Semangat kerja sebagai mediasi motivasi terhadap komitmen pegawai yakni dengan indirect :

$$
\begin{gathered}
\mathrm{X} 1->\mathrm{Z}->\mathrm{Y}=0,130 \times 0,273=0,036 \\
\text { Dan dengan direct }: \\
\mathrm{X} 1->\mathrm{Y}=0,031
\end{gathered}
$$

Perhitungan tersebut menunjukkan bahwa variabel motivasi secara sigifikan berpengaruh terhadap semangat kerja dengan nilai koefisien sebesar 0,130 dan semangat kerja secara signifikan berpengaruh terhadap komitmen pegawai dengan nilai koefisien sebesar 0,273. Sedangkan koefisien jalur dari variabel motivasi yang dimediasi oleh semangat kerja secara signifikan mampu mempengaruhi komitmen pegawai dengan nilai koefisien sebesar 0,036. Selanjutnya, nilai tersebut mempunyai nilai koefisien lebih besar dari motivasi terhadap komitmen pegawai dengan nilai koefisien sebesar 0,031. Setelah membandingkan nilai antara hubungan langsung dengan tidak langsung yang diperoleh dari perhitungan tersebut, maka dapat diambil 
kesimpulan bahwa nilai koefisien direct lebih kecil dari indirect. Dengan demikian dapat dikatakan bahwa semangat kerja berperan sebagai mediasi penuh (full mediation) dari efek tidak langsung pengaruh antara motivasi kerja dan komitmen pegawai. Dapat diartikan bahwa ketika motivasi kerja yang diterapkan pada Dinas Pariwisata baik, maka semangat kerja juga akan baik yang nantinya juga berpengaruh pada komitmen pegawai.

\section{KESIMPULAN}

Berdasarkan paparan pembahasan yang telah diuraikan diketahui bahwa pengaruh secara langsung variabel motivasi kerja, kepuasan kerja, semangat kerja berpengaruh signifikan terhadap komitmen pegawai Dinas pariwisata Kota Batu. Disisi lain, variabel semangat kerja dikatahui bahwa pengaruh secara tidak langsung mampu menjadi mediasi antara motivasi kerja dan kepuasan kerja terhadap komitmen pegawai Dinas Pariwisata Kota Batu.

\section{DAFTAR KEPUSTAKAAN}

Allen, Natalie J., and John P. Meyer. 1990. "Organizational Socialization Tactics: A Longitudinal Analysis of Links to Newcomers' Commitment and Role Orientation." Academy of Management Journal 33, No. 4.

Arikunto, Suharsimi. 2010. "Metode Peneltian." Jakarta: Rineka Cipta.

Assagaf, Shannon Cecilia Y., and Lucky Oh Dotulong. 2015. "Pengaruh Disiplin, Motivasi Dan Semangat Kerja Terhadap Produktivitas Kerja Pegawai Dinas Pendapatan Daerah Kota Manado." Jurnal Emba: Jurnal Riset Ekonomi, Manajemen, Bisnis Dan Akuntansi 3, No. 2.

Badriyah, Mila. 2015. "Manajemen Sumber Daya Manusia." Bandung: Cv Pustaka Setia $(2$

Bell-Ellis, Rhonda, Linda C. Jones, Molly Longstreth, and Judi Neal. 2013, "FaithRelated Determinants of Employee commitment." In Handbook of Faith And
Spirituality In The Workplace, Pp. 345-379. Springer, New York.

Camilleri, Emanuel, and Beatrice Ijm Van Der Heijden. 2007. "Employee commitment, Public Service Motivation, And Performance Within the Public Sector." Public Performance \& Management Review 31, No. 2.

Carlaw, Deming. "Friedman. 2003. Managing \& Motivating Contact Center Employees."

Chaplin, Kevin. 2015. "The Ubuntu Spirit in African Communities." Retrieved January 30 (2006).

Chen, Ching-Fu. 2006. "Job Satisfaction, Employee commitment, And Flight Attendants' Turnover Intentions: A Note." Journal of Air Transport Management 12, No. 5.

Davis, Thomas. 2000. Sustaining the Forest, The People, And The Spirit. Albany: State University Of New York Press.

Donelly, Jh, Jl Gibson, and Jm Ivancevich. 2007. "Management Praha."

Echols, John M., and Hasan Shadily. 2019. "Kamus Indonesia-Inggris."

Effendi, Marihot Tua. 2005. "Msdm Pengadaan, Pengembangan, Pengkompensasian, dan Peningkatan Produktivitas Pegawai."

Erwin, Tri Hardiono, Jemmy Rumengan, and Angelina Eleonora Rumengan. 2019. "Determination of Competence, Work Spirit and Work Environment With Work Motivation As Intervening Variables Against Performance Of Employee Services Riau Islands Province." Zona Manajemen: Program Studi Magister Sains Manajemen Universitas Batam 9, No. 2.

Flippo, Edwin B. 2019. "Manajemen Personalia."

Gilbert, Jacqueline A., and John M. Ivancevich. 1999 "A Re-Examination of Employee commitment." Journal of Social Behavior and Personality 14, No. 3.

Greenberg, Jerald, Robert A. Baron, and Richard A. Grover. 1993. "Behavior in Organizations: Understanding And Managing The Human Side Of Work." 
Handoko, T. Hani. 2000 "Manajemen Personalia Dan Manajemen Sumber Daya Manusia." Yogyakarta: Bpfe.

Hasibuan, Malayu. "Drs., 2004." Manajemen Sumber Daya Manusia, Edisi Revisi, Jakarta: Pt. Bumi Aksara.D

Hasibuan, H. "Malayu Sp 2005." Manajemen Sumber Daya Manusia.

Hasibuan, S. P. "Malayu. 2009." Manajemen Sumber Daya Manusia.

Hougaard, Anders, Ulrich Lindberg, Nanna Arngrim, Henrik Bw Larsson, Jes Olesen, Faisal Mohammad Amin, Messoud Ashina, and Bryan T. Haddock. 2015. "Evidence of A Christmas Spirit Network in The Brain: Functional Mri Study." Bmj 351.

Hughes, Richard L., Robert C. Ginnett, and Gordon J. Curphy. 2012. "Leadership: Memperkaya Pelajaran Dari Pengalaman." Edisi Ketujuh, Jakarta: Salemba Humanika.

Indrajaya, Amelia Naim, Wiwiek Mardawiyah Daryanto, Cut Sjahrifa, and Shirley Yeung. 2019 "The Interaction of Spiritual Leadership and Individual Spirituality Impacting Spirit At Work Toward Enhancing Employee commitment And Job Satisfaction: A Conceptual Proposition." Journal Of Law and Society Management 6, No. 1.

Indonesia, Pemerintah. Undang-Undang Nomor 22 Tabun 1999 Tentang Pemerintahan Daerah. Bagian Proyek Peningkatan Publikasi Pemerintah, Direktorat Publikasi, Ditjen Ppg, Deppen Ri, 1999.

Jaichitra, D., and P. T. Srinivasan. 2018. "Individual Spirit at Work and Its Relationship With Job Satisfaction And Personal Outcomes." Indian Journal of Public Health Research \& Development 9, No. 2.

Joo, Baek-Kyoo Brian, and Sunyoung Park. 2010. "Career Satisfaction, Employee commitment, And Turnover Intention." Leadership \& Organization Development Journal.

Karsini, Karsini, Patricia Dhiana Paramita, and Maria Magdalena Minarsih. 2016. "Pengaruh Semangat Kerja Dan Disiplin Kerja Terhadap Kepuasan Kerja Yang
Berdampak Pada Kinerja Pegawai Dinas Pengelolaan Keuangan Dan Aset Daerah (Dpkad) Kota Semarang." Journal of Management 2, No. 2.

Kinjerski, Val, and Berna J. Skrypnek. 2008. "The Promise of Spirit at Work Increasing Job Satisfaction and Employee commitment And Reducing Turnover And Absenteeism In LongTerm Care." Journal of Gerontological Nursing 34, No. 10.

Koesmono, H. Teman. 2005. "Pengaruh Budaya Organisasi Terhadap Motivasi dan Kepuasan Kerja Serta Kinerja Karyawan Pada Sub Sektor Industri Pengolahan Kayu Skala Menengah Di Jawa Timur." Jurnal Manajemen Dan Kewirausahaan 7, No. 2.

Lambert, Eric G., Nancy L. Hogan, and Marie L. Griffin. 2007. "The Impact of Distributive and Procedural Justice On Correctional Staff Job Stress, Job Satisfaction, And Employee commitment." Journal of Criminal Justice 35, No. 6.

Locke, Edwin 1968. "Toward A Theory of Task Motivation and Incentives." Organizational Behavior and Human Performance 3, No. 2.

Lum, Lillie, John Kervin, Kathleen Clark, Frank Reid, and Wendy Sirola. 1998. "Explaining Nursing Turnover Intent: Job Satisfaction, Pay Satisfaction, Or Employee commitment." Journal of Organizational Behavior: The International Journal of Industrial, Occupational and Organizational Psychology and Behavior 19, No. 3.

Luthans, Fred, Bruce J. Avolio, James B. Avey, and Steven M. Norman. 2007. "Positive Psychological Capital: Measurement and Relationship with Performance and Satisfaction." Personnel Psychology 60, No. 3.

Ngambi, Hellicy Chakosamoto. 2011. Rare Total Leadership: Leading with The Head, Heart And Hands. Juta And Company Ltd.

Majorsy, Ursa. 2011 "Kepuasan Kerja, Semangat Kerja dan Komitmen pegawai pada Staf Pengajar Universitas Gunadarma." Jurnal Psikologi 1, No. 1. 
Mangkunegara, Anwar Prabu, and Anwar Prabu. 2005. "Perilaku Dan Budaya Organisasi." Bandung: Refika Aditama.

Mathis, Robert L., and H. John. "Jackson. 2006." Human Resources Development (Track Mba Series/Terjemahan).

Meyer, John P., Natalie J. Allen, and Catherine A. Smith. 1993. "Commitment to Organizations and Occupations: Extension and Test of a ThreeComponent Conceptualization." Journal Of Applied Psychology 78, No. 4.

Moynihan, Donald P., and Sanjay K. Pandey. 2007. "Finding Workable Levers Over Work Motivation: Comparing Job Satisfaction, Job Involvement, and Employee commitment." Administration \& Society 39, No. 7.

Muhadi, Muhadi. 2007. "Analisis Pengaruh Kepuasan Kerja Terhadap Komitmen pegawai dalam Mempengaruhi Kinerja Karyawan (Studi pada Karyawan Administrasi Univeristas Diponegoro)." Phd Diss., Program Pascasarjana Universitas Diponegoro.

Munandar, Ashar Sunyoto. 2001. Psikologi Industri dan Organisasi. Universitas Indonesia (Ui-Press).

Murty, Windy Aprilia. 2012. "Pengaruh Kompensasi, Motivasi dan Komitmen pegawai Terhadap Kinerja Karyawan Bagian Akuntansi (Studi Kasus pada Perusahaan Manufaktur di Surabaya)." Phd Diss., Stie Perbanas Surabaya.

Naziah, Risyatun, Caska Caska, Syakdanur Nas, and Henny Indrawati. 2020. "The Effects of Contextual Learning and Teacher's Work Spirit on Learning Motivation And Its Impact On Affective Learning Outcomes." Journal of Educational Sciences 4, No. 1.

Nazir, Moh. 1999. "Metode Penelitian, Jakarta: Ghalia Indonesia." Cet. Iv.

Nguni, Samuel, Peter Sleegers, and Eddie Denessen. 2006. "Transformational and Transactional Leadership Effects on Teachers' Job Satisfaction, Employee commitment, and Organizational Citizenship Behavior in Primary Schools: The Tanzanian Case." School Effectiveness and School Improvement 17, No. 2.
Nitisemito, Alex S. 1992. "Management and Human Resources." Bpfe Ugm. Yogyakarta.

Posey, Clay, Tom L. Roberts, and Paul Benjamin Lowry. 2015. "The Impact of Employee commitment On Insiders' Motivation to Protect Organizational Information Assets." Journal of Management Information Systems 32, No. 4.

Qaiser Danish, Rizwan, Natasha Ali, Hafiz Fawad Ali, Asad Afzal Humayon, Muhammad Bilal Ahmad, and Amna Gohar. 2019. "Spirit And Innovation At Work In Software Houses Of Pakistan: How Does Job Satisfaction Intervene the Relationship?." European Online Journal of Natural and Social Sciences: Proceedings 8, No. 1.

Riorini, Sri Vandayuli. 2004. "Quality Performance dan Komitmen Organisasi." Jurnal Media Riset Bisnis Dan Manajemen 4, No. 3.

Robbins, Stephen. "P, Luthan." 2008. Perilaku Organisasi.

Robbin, Stephen P., and T. Judge. 2007. "Perilaku Organisasi Buku 1." Jakarta: Salemba Empat.

Robbin, Stepen P., and Timothy A. Judge. 2007. "Alih Bahasa Diana Angelica. 2008." Perilaku Organisasi.

Samsudin, Endang. 2019. "Pengaruh Motivasi dan Kemandirian Belajar Terhadap Hasil Belajar Ipa Siswa (Survey pada Sekolah Menengah Pertama (SMP) Negeri di Kecamatan Telagasari Karawang)." Biodidaktika: Jurnal Biologi Dan Pembelajarannya 14, No. 1.

Sari, Agrisna Puspita. 2014. "Pengaruh Kompensasi, Iklim Kerja, Semangat Kerja, dan Karakteristik Karyawan Terhadap Kinerja Karyawan Melalui Kepuasan Kerja Sebagai Variabel Intervening." Studi Pada Pt Bank Bukopin Tbk Cabang Sultan Agung.

Sastrohadiwiryo, Siswanto. 2003. "Pengantar Manajemen."

Scandura, Terri A., and Melenie J. Lankau. 1997. "Relationships of Gender, Family Responsibility and Flexible Work Hours To Employee commitment And Job Satisfaction." Journal of Organizational 
Behavior: The International Journal of Industrial, Occupational and Organizational Psychology And Behavior 18, No. 4.

Sedarmayanti, Manajemen Sumber Daya Manusia Reformasi. 2009. "Birokrasi dan Manajemen Pegawai Negeri Sipil." Rafika Aditama, Bandung.

Septyanto, Dihin. 2008. "Pengukuran Variabel dalam Penelitian." Pascasarjana Universitas Indonusa.

Siagian Sondang, P. 2009. "Manajemen Sumber Daya Manusia." Bpfe, Ugm, Yogyakarta.

Sopiah, Syihabudhin, And M. Pd. 2008. "Manajemen Bisnis Ritel." Yogyakarta: Penerbit Andi.

Sp, Malayu. "Hasibuan, 2010." Manajemen Sumber Daya Manusia.

Stum, David L. 1999. "Workforce Commitment: Strategies for The New Work Order." Strategy \& Leadership.

Sugiyono, P. D. 2017. "Metode Penelitian Bisnis: Pendekatan Kuantitatif, Kualitatif, Kombinasi, Dan R\&D." Penerbit Cv. Alfabeta: Bandung.

Sugiyono, Sugiyono. 2010. "Metode Penelitian Kuantitatif dan Kualitatif dan R\&D."

Sulistiyani, Ambar Teguh, and Rosidah. 2003. Manajemen Sumber Daya Manusia: Konsep, Teori Dan Pengembangan dalam Konteks Organisasi Publik. Graha Ilmu.

Supardi, Suhardjono, and Arikunto Suharsimi. 2009. "Penelitian Tindakan Kelas." Jakarta: Bumi Aksara.

Sunyoto, Danang. 2013. "Perilaku Konsumen." Caps (Center Of Academy Publishing Service), Yogyakarta.

Suryantoro, Igor, Maswardi Amin, and M. Chiar. 2018. "The Effect of Compensation and Motivation to Spirit at Work of Elementary School Teachers in Hulu Sungai Sub-District of Ketapang Regency." Journal of Education, Teaching and Learning 3, No. 2.

Sutanto, Eddy Madiono, and Carin Gunawan. 2013. "Kepuasan Kerja, Komitmen pegawai dan Turnover Intentions." Jurnal Mitra Ekonomi dan Manajemen Bisnis 4, No. 1.

Sutrisno, Edi. 2009. "Manajemen Sumber Daya Manusia Edisi Pertama." Jakarta: Kencana Prenada Media Group.
Tobing, Diana Sulianti KL. 2009. "Pengaruh Komitmen pegawai dan Kepuasan Kerja Terhadap Kinerja Karyawan PT. Perkebunan Nusantara III di Sumatera Utara." Jurnal Manajemen dan Kewirausahaan 11, No. 1.

Tohardi, Ahmad. 2002. "Pemahaman Praktis Manajemen Sumber Daya Manusia." Universitas Tanjung Pura, Mandar Maju, Bandung.

Van Latham, M., and Peter M. Leddy. 1987. "Source of Recruitment and Employee Attitudes: An Analysis of Job Involvement, Employee commitment, and Job Satisfaction." Journal Of Business and Psychology 1, No. 3.

Wagner, Joan Ij, Sharon Warren, Greta Cummings, Donna L. Smith, and Joanne K. Olson. 2013. "Resonant Leadership, Workplace Empowerment, And" Spirit at Work": Impact On Rn Job Satisfaction And Employee commitment." Canadian Journal of Nursing Research Archive 45, No. 4.

Wagner, Joan. 2010. "Exploring The Relationships Among Spirit At Work, Structural and Psychological Empowerment, Resonant Leadership, Job Satisfaction And Employee commitment In The Health Care Workplace."

Widdyatatik, Widdyatatik, Prasetyo Ichtiarto, and Sunyoto Sunyoto. 2011. "Tinjauan Tentang Peranan Banquet Service Terhadap Tingkat Kepuasan Tamu Dalam Penyelenggaraan Event Di Hotel the Sunan Surakarta." Jurnal Pariwisata Indonesia 6, No. 2.

Winardi, Yonathan, and Ridwanta Manogu. "Students'perception On the Role Of The Holy Spirit In Learning English: A Survey In Uph Teachers College."

Wursanto, I. G. 2001. "Analisis Kebijakan Publik." Bandung: Tarsito.

Young, Suzanne, and Vijaya Thyil. 2008. "Building Commitment Through Integrating Employees." The Business Review, Cambridge 11, No. 2. 